\title{
Adenosine Nucleotide Transporter
}

National Cancer Institute

\section{Source}

National Cancer Institute. Adenosine Nucleotide Transporter. NCI Thesaurus. Code C37297.

A family of mitochondrial proteins that catalyze the exchange of ADP and ATP across the inner mitochondrial membrane. There are four nuclear genes, which are members of the solute carrier family 25 mitochondrial carrier family, that each encode cell-type specific isoforms of the transporter. 